\title{
FUNKCJONOWANIE DUSZPASTERSTW WIEZZIENNYCH WYRAZEM RÓWNOUPRAWNIENIA KOŚCIOŁÓW I ZWIĄZKÓW WYZNANIOWYCH W POLSCE
}

Zasada równouprawnienia kościołów i związków wyznaniowych wobec państwa jest jedną z najistotniejszych w systemie współczesnego polskiego prawa wyznaniowego. Zawarta w art. 25 ust. 1 Konstytucji Rzeczypospolitej Polskiej z dnia 2 kwietnia 1997 r. ${ }^{1}$ głosi, iż: „Kościoły i inne związki wyznaniowe są równouprawnione”. Stanowi ona podstawowy element demokratycznego państwa świeckiego ${ }^{2}$ i wyklucza nadanie temu państwu charakteru wyznaniowego, albowiem uniemożliwia jakiejkolwiek wspólnocie religijnej z formalnoprawnego punktu widzenia uzyskanie statusu wyznania uprzywilejowanego - państwowego czy też narodowego lub dominującego ${ }^{3}$. Jak wskazuje

${ }^{*}$ Dr hab. prof. UO, Katedra Historii Państwa i Prawa oraz Doktryn Polityczno-Prawnych, Wydział Prawa i Administracji, Uniwersytet Opolski, ul. Katowicka 87a, 45-060 Opole, e-mail: andrzej@kozle.pl

${ }^{1}$ Dz.U. Nr 78, poz. 483 z późn. zm.

2 Józef Krukowski, Krzysztof Warchałowski, Polskie prawo wyznaniowe (Warszawa: Wydawnictwo Lexis Nexis, 2000), 59.

${ }^{3}$ Wojciech Góralski, Wstęp do prawa wyznaniowego (Płock: Płocki Instytut Wydawniczy, 2003), 96. Cyt. za Paweł Borecki, „Zasada równouprawnienia wyznań w prawie polskim", Studia z Prawa Wyznaniowego 10 (2007): 115. 
Mirosław Sitarz, zasadę równouprawnienia odczytać można „z zasad relacji Kościół - państwo, w szczególności określonych przez Sobór Watykański II"4. Jej ujęcie w aktualnej polskiej ustawie zasadniczej „znajduje swe najgłębsze uzasadnienie w uznanej przez ustrojodawcę przyrodzonej godności człowieka (art. 30)"5. Dlatego też w ustawie z dnia 17 maja 1989 r. o gwarancjach wolności sumienia i wyznania ${ }^{6}$ „równouprawnienie wszystkich związków wyznaniowych, bez względu na formę regulacji ich sytuacji prawnej, potraktowane jest jako jedna z gwarancji wolności sumienia i wyznania (art. 9 ust. 2. )"7.

W doktrynie prawa konstytucyjnego i wyznaniowego znajdują odzwierciedlenie różne interpretacje omawianej zasady ${ }^{8}$. Jan Boć twierdzi oto, że ,zasada równouprawnienia sformułowana dla kościołów i innych związków wyznaniowych oznacza, że każdemu z wyżej wymienionych podmiotów z powodu takiej samej sytuacji faktycznej i prawnej zostaną przydane takie same obowiązki lub takie same uprawnienia"9. Piotr Winczorek mówi z kolei, że „,z zasady równouprawnienia wynika, że żaden z kościołów i innych związków wyznaniowych nie może być prawnie uprzywilejowany, natomiast prawa i obowiązki dotyczące jednego z nich, mogą dotyczyć każdego z pozostałych"10. Józef Krukowski domaga się natomiast, aby przy egzegezie zasady równouprawnienia uwzględnione zostało kryterium „równouprawnienia różnych podmiotów należących do tego samego zbioru”. Wskazuje na konieczność odrzucenia postulatów ,Zwolenników prymitywnego

${ }^{4}$ Mirosław Sitarz, ,Zasada równouprawnienia kościołów i innych związków wyznaniowych”, Kościót i Prawo 4 (2015): 141, 161.

${ }^{5}$ Piotr Stanisz, „Naczelne zasady instytucjonalnych relacji państwo - kościół”, w: Artur Mezglewski, Henryk Misztal, Piotr Stanisz, Prawo wyznaniowe (Warszawa: Wydawnictwo C.H. Beck, 2011), 76.

${ }^{6}$ Tekst jedn. Dz.U. z 2005 r. Nr 231, poz. 1965 z późn. zm.

${ }^{7}$ Stanisz, „Naczelne zasady instytucjonalnych relacji”, 76.

${ }^{8}$ Sitarz, ,Zasada równouprawnienia”, 157 i n.

9 Jan Boć, „Rozdział I. Rzeczpospolita”, w: Konstytucje Rzeczypospolitej Polskiej oraz komentarz do konstytucji RP z 1997 r., red. Jan Boć (Wrocław: Wydawnictwo Kolonia Limited, 1998), 62.

${ }^{10}$ Piotr Winczorek, Komentarz do Konstytucji Rzeczypospolitej Polskiej z dnia 2 kwietnia 1997 roku (Warszawa: Wydawnictwo „Liber”, 2008), 65. Cyt. za Sitarz, „Zasada równouprawnienia kościołów i innych związków wyznaniowych”, 158. 
egalitaryzmu, utożsamiających równouprawnienie z identycznością", która miałaby miejsce w sytuacji, gdyby „słabsi” (czyli np. najmniej liczny związek wyznaniowy), odwołując się do zasady równouprawnienia, starali się „ściągnąć silniejszych do swego poziomu" ${ }^{11}$. Poprawne zatem wg Krukowskiego i grupy autorów związanych z Katolickim Uniwersytetem Lubelskim Jana Pawła II oraz z Uniwersytetem Kardynała Stefana Wyszyńskiego byłoby - jak pisze Paweł Borecki - „wzięcie pod uwagę takich cech, które są wspólne dla wszystkich związków wyznaniowych, a jednocześnie uwzględnienie występujących między nimi różnic ${ }^{12}$ ”. I dalej: „w myśl tej koncepcji zasada równouprawnienia zobowiązuje do traktowania wyznań identycznie w tych dziedzinach, w których każdy ze związków wyznaniowych posiada w identycznym stopniu określoną cechę. Jeżeli natomiast między Kościołami i innymi związkami wyznaniowymi zachodzą poważne różnice, to należy traktować każde $\mathrm{z}$ nich odmiennie, zawsze odpowiednio do tego zróżnicowania" "13. W tym kontekście „nie sprzeciwia się zasadzie równouprawnienia np. fakt, że stosunek państwa do Kościoła katolickiego został określony poprzez konkordat, podczas gdy sytuacja prawna pozostałych związków wyznaniowych jest regulowana w ustawodawstwie zwykłym"14. Żaden bowiem związek wyznaniowy - poza Kościołem katolickim - nie może uczestniczyć w stosunkach międzynarodowych $^{15}$. Sitarz podkreśla także, że Trybunał Konstytucyjny w wyroku z dnia 2 kwietnia 2003 r. (sygn. akt K 13/02) po rozpoznaniu wniosku

${ }^{11}$ Krukowski, Warchałowski, Polskie prawo wyznaniowe, 59.

${ }^{12}$ Tamże. Zob. także Paweł Sobczyk, ,Konstytucyjna zasada równouprawnienia Kościołów i innych związków wyznaniowych", w: Problemy państwa i prawa, red. Feliks Prusak (Warszawa: Oficyna Wydawnicza WSM SIG, 2004), 21-35.

${ }^{13}$ Paweł Borecki, „Zasada równouprawnienia wyznań w prawie polskim”, Studia z Prawa Wyznaniowego 10 (2007): 135. Cytowany wywód P. Borecki opiera na analizie następujących prac: Wojciech Góralski, Wstęp do prawa, 96-97, Krukowski, Warchałowski, Polskie prawo wyznaniowe, 58-60, Józef Krukowski, Kościót i państwo. Podstawy relacji prawnych (Lublin: Redakcja Wydawnictw KUL, 2000), 277, Artur Mezglewski, Henryk Misztal, Piotr Stanisz, Prawo wyznaniowe (Warszawa: Wydawnictwo C.H. Beck, 2006), 71.

${ }^{14}$ Henryk Misztal, „Konstytucyjne podstawy polskiego prawa wyznaniowego”, w: Prawo wyznaniowe, red. Henryk Misztal, Piotr Stanisz (Lublin: Wydawnictwo Diecezjalne w Sandomierzu, 2003), 198.

${ }^{15}$ Tamże. 
Polskiego Autokefalicznego Kościoła Prawosławnego stwierdził, iż „wszystkie kościoły i związki wyznaniowe posiadające wspólną cechę istotną powinny być traktowane równo. Jednocześnie zasada ta zakłada odmienne traktowanie kościołów i związków wyznaniowych, które nie posiadają wspólnej cechy istotnej z punktu widzenia danej regulacji”'16.

Borecki wskazuje na interesujące zdefiniowanie opisywanej materii przez W. Adamczewskiego i B. Trzeciaka, którzy proponują sformułowanie, że „związki wyznaniowe są równe wobec prawa" ${ }^{17}$. Jego zdaniem taki zapis zapewniłby równe traktowanie wszystkich kościołów przy poszanowaniu wszelkich różnic między nimi zachodzących ${ }^{18}$. Tenże autor wskazuje ponadto na „optymalną, zgodną z wykładnią językową odpowiednich przepisów konstytucyjnych i ustawowych" interpretację zasady równouprawnienia kościołów i związków wyznaniowych ukutą przez adwentystycznego duchownego, ks. prof. Zachariasza $Ł y k e^{19}$, który równouprawnienie rozumie jako „prawo jednakowych szans, czyli takich samych możliwości prawnych dla związków wyznaniowych". W tym przypadku zakres korzystania z owych możliwości nie jest uzależniony od różnic dzielących związki wyznaniowe lecz od ich rzeczywistych możliwości, takich jak liczebność, aktywność, znaczenie etc. ${ }^{20}$

Wszystkie zaprezentowane interpretacje, różniące się w szczegółach, w tym co najważniejsze są jednak do siebie podobne, uwzględniają bowiem zasadniczo te same podstawy aksjologiczne i prawne, nie zawsze wymieniane wprost ${ }^{21}$. Zakładają sprawiedliwe [podkreślenie AS] traktowanie przez państwo wszystkich kościołów i związków

${ }^{16}$ Sitarz, „Zasada równouprawnienia kościołów i innych związków wyznaniowych”, 158. Cytowany wyrok TK opublikowany na stronie internetowej: http://otk.trybunal.gov.pl/ orzeczenia/teksty/otkpdf/2003/K_13_02.pdf, [dostęp: 29.12.2015].

${ }^{17}$ Borecki, ,Zasada równouprawnienia wyznań”, 135.

${ }_{18}$ Tamże, 135.

19 Tamże, 138.

${ }^{20}$ Zbigniew Łyko, „Wolność sumienia i wyznania w relacji: człowiek - kościoły państwo", w: Podstawowe prawa jednostki i ich sądowa ochrona, red. Leszek Wiśniewski (Warszawa: Wydawnictwo Sejmowe, 1997), 96. Cyt. za Borecki, ,Zasada równouprawnienia wyznań", 138.

${ }^{21}$ Sitarz, „Zasada równouprawnienia kościołów i innych związków wyznaniowych”, 157. 
wyznaniowych z pozytywnym i życzliwym uwzględnieniem różnic między nimi występujących, samą ideę równouprawnienia wyprowadzając z przyrodzonej godności osoby ludzkiej, równości, wolności sumienia i religii, a co za tym idzie - z poszanowania społeczeństwa pluralistycznego czyli w konsekwencji - podstaw demokratycznego państwa prawnego.

Jedną z konsekwencji tak pojmowanego równouprawnienia kościołów i innych związków wyznaniowych jest umożliwienie im sprawowania opieki duszpasterskiej nad swoimi wyznawcami znajdującymi się w różnych sytuacjach życiowych - także przebywających w zakładach penitencjarnych.

Jak wskazuje Jerzy Nikołajew „duszpasterstwo więzienne stanowi [...] na tyle istotny element polityki penitencjarnej każdego państwa, że pomijając lub dyskryminując je pozbawia się więźniów jedynego dla nich azylu - miejsca na i dla Boga"22. Ten sam autor uzupełnia: „W celu właściwego zapewnienia skazanym i tymczasowo aresztowanym wolności sumienia i religii niezbędna jest właściwa organizacja duszpasterstwa więziennego. Jego funkcjonowanie ma zapewnić należytą ochronę praw religijnych więźniów. Struktura duszpasterstwa więziennego [...] powinna wynikać z potrzeb określonych społeczności religijnych funkcjonujących w systemie penitencjarnym. Osoby posiadające status kapelański wykonują swoje posługi w ramach stosunku pracy, bądź na zasadzie wolontariatu. Zagadnieniem szczególnej wagi jest określenie wzajemnych relacji pomiędzy władzą kościelną i świecką w zakresie podległości duchownych opłacanych przez państwo.

${ }^{22}$ Jerzy Nikołajew, „Miejsce duszpasterstwa penitencjarnego w powrocie do wolności skazanych na podstawie Kodeksu Karnego Wykonawczego z 1997 roku i rozwiązań innych państw”, w: Stefan Lelental, Grażyna B. Szczygieł, X lat obowiąywania Kodeksu Karnego Wykonawczego (Białystok: Wydawnictwo Temida 2, 2009), 381. 
Ważne zadania pastoralne spełniają także osoby świeckie i organizacje wspomagające duszpasterstwo więzienne"23.

Podstawą prawną dla korzystania przez osoby pozbawione wolności z prawa do wolności religijnej ${ }^{24}$, a co za tym idzie, z posługi duszpasterstwa więziennego różnych wyznań w Polsce, są akty prawne o randze międzynarodowej i te, które stanowią część krajowego porządku prawnego. Zalicza się do nich m.in.:

- Powszechną Deklarację Praw Człowieka z 10 grudnia 1948 r. ${ }^{25}$,

- Wzorcowe Reguły Minimum Postępowania z Więźniamiª,

${ }^{23}$ Jerzy Nikołajew, Wolność sumienia $i$ religii osób skazanych i tymczasowo aresztowanych $w$ zaktadach karnych $i$ aresztach śledczych (Lublin, 2010), 170, mps $w$ posiadaniu autora.

${ }^{24} \mathrm{Na}$ ten temat także Anna Komadowska, „Prawo skazanego do korzystania z wolności religijnej a zasada humanitaryzmu", w: Wolność sumienia i religii osób pozbawionych wolności. Aspekty prawne i praktyczne, red. Jerzy Nikołajew, Konrad Walczuk (Warszawa: Wydawnictwo Unitas, 2016), 115-127; Piotr Wiśniewski, „Osoba pozbawiona wolności - na podstawie wyroku lub postanowienia sądu - jako podmiot konstytucyjnej gwarancji wolności sumienia i religii. Aspekt teoretyczny. Zagadnienia wybrane", w: Wolność sumienia $i$ religii osób pozbawionych wolności. Aspekty prawne i praktyczne, 97-111; Paweł Sobczyk, „Konstytucyjne «prawo osób do korzystania z pomocy religijnej tam, gdzie się znajdują»", w: Wolność sumienia i religii osób pozbawionych wolności. Aspekty prawne i praktyczne, 82-96.

${ }^{25} \mathrm{http}$ ://www.unesco.pl/fileadmin/user_upload/pdf/Powszechna_Deklaracja_Praw_Czlowieka.pdf, [dostęp: 3.01.2016]. Art. 18 stanowi: „Każdy człowiek ma prawo do wolności myśli, sumienia i religii".

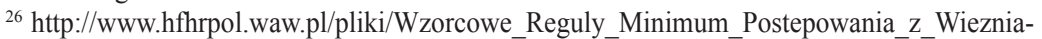
mi.pdf, [dostęp: 4.01.2016]. ,Religia 41. (1) W zakładzie, w którym przebywa wystarczająca liczba więźniów tego samego wyznania, ustanawia się lub dopuszcza kanonicznie uprawnionego przedstawiciela tego wyznania. O ile usprawiedliwia to liczba więźniów i o ile pozwalają na to warunki, powinno się ustanowić lub dopuścić tego przedstawiciela w wymiarze czasu odpowiadającym pełnemu etatowi. (2) Kanonicznie uprawnionemu przedstawicielowi, ustanowionemu lub dopuszczonemu zgodnie z ust. 1, umożliwia się odprawianie nabożeństw oraz składanie na osobności więźniom wizyt duszpasterskich w wymaganych przez daną religię przypadkach. (3) Żadnemu więźniowi nie odmówi się dostępu do kanonicznie uprawnionego przedstawiciela jakiejkolwiek religii. Z drugiej strony, jeżeli jakiś więzień sprzeciwi się wizycie przedstawiciela jakiejś religii, jego postawa będzie w pełni respektowana. 42. Każdemu więźniowi zezwala się, na ile jest to możliwe, na zaspokojenie jego potrzeb życia religijnego przez uczestnictwo w nabożeństwach organizowanych w zakładzie oraz na posiadanie religijnych książek dogmatycznych i pouczających w zakresie jego wyznania". We Wzorcowych Regułach Minimum Postępowania z Więźniami opieka duszpasterska wydaje się być traktowana jako jeden ze sposobów resocjalizacji osób pozbawionych wolności, co wynika z treści reguł 55 i 56, http://www.edwi.pl/wp-content/uploads/2010/11/Podstawy-prawne-dzialalnosci-kosciolow.pdf, [dostęp: 4.01.2016]. 
- Europejskie Reguły Więzienne ${ }^{27}$,

- Konstytucja Rzeczypospolitej Polskiej z dnia 2 kwietnia 1997 roku $^{28}$,

- Ustawa z dnia 17 maja 1989 r. o gwarancjach wolności sumienia i wyznania ${ }^{29}$,

${ }^{27}$ Zob. Monika Płatek, „Europejskie Reguły Więzienne a polskie prawo i praktyka penitencjarna", Studia Iuridica 34 (1997): 167 i n. http://www.wuw.pl/ksiegarnia/tresci/ studiaiuridica/34/34_8.pdf, [dostęp: 3.01.2016]. Artykuł 46: „Każdemu więźniowi umożliwia się, tak dalece jak to wykonalne, zaspokajanie potrzeb religijnych, duchowych oraz moralnych przez uczestniczenie w posługach lub spotkaniach organizowanych w zakładzie, a także na posiadanie wszelkich niezbędnych książek lub lektury”. Artykuł 47: „1. W zakładzie, w którym przebywa wystarczająca liczba więźniów tego samego wyznania, ustanawia się oraz zatwierdza uprawnionego przedstawiciela tego wyznania. O ile usprawiedliwia to liczba więźniów i pozwalają na to warunki, powinno się go zatrudnić na pełnym etacie. 2 . Uprawnionemu przedstawicielowi ustanowionemu lub uznanemu zgodnie z ust. 1, umożliwia się regularne wykonywanie posług religijnych i praktyk oraz składania na osobności wizyt duszpasterskich w wymaganych przez daną religię przypadkach. 3. Żadnemu więźniowi nie odmówi się dostępu do uprawnionego przedstawiciela jakiejkolwiek religii. Jeżeli którykolwiek więzień sprzeciwi się wizycie jakiegoś przedstawiciela religijnego, jego wola będzie uszanowana", http://agb.waw.pl/cms/index.php/prawo/7-regulacje-prawne/241europejskie-regoy-wizienne, [dostęp: 12.01.2016].

28 Art. 25: „1. Kościoły i inne związki wyznaniowe są równouprawnione. 2. Władze publiczne w Rzeczypospolitej Polskiej zachowują bezstronność w sprawach przekonań religijnych, światopoglądowych i filozoficznych, zapewniając swobodę ich wyrażania w życiu publicznym. 3. Stosunki między państwem a kościołami i innymi związkami wyznaniowymi są kształtowane na zasadach poszanowania ich autonomii oraz wzajemnej niezależności każdego w swoim zakresie, jak również współdziałania dla dobra człowieka i dobra wspólnego. 4. Stosunki między Rzecząpospolitą Polską a Kościołem Katolickim określają umowa międzynarodowa zawarta ze Stolicą Apostolską i ustawy. 5. Stosunki między Rzecząpospolitą Polską a innymi kościołami oraz związkami wyznaniowymi określają ustawy uchwalone na podstawie umów zawartych przez Radę Ministrów z ich właściwymi przedstawicielami”.

${ }^{29}$ Art. 2: „Korzystając z wolności sumienia i wyznania obywatele mogą w szczególności: 1) tworzyć wspólnoty religijne, zwane dalej „kościołami i innymi związkami wyznaniowymi”, zakładane w celu wyznawania i szerzenia wiary religijnej, posiadające własny ustrój, doktrynę i obrzędy kultowe; 2) zgodnie z zasadami swojego wyznania uczestniczyć w czynnościach i obrzędach religijnych oraz wypełniać obowiązki religijne i obchodzić święta religijne; 2a) należeć lub nie należeć do kościołów i innych związków wyznaniowych; 3) głosić swoją religię lub przekonania; 4) wychowywać dzieci zgodnie ze swoimi przekonaniami w sprawach religii; 5) zachowywać milczenie w sprawach swojej religii lub przekonań; 6) utrzymywać kontakty ze współwyznawcami, w tym uczestniczyć w pracach organizacji religijnych o zasięgu międzynarodowym; 7) korzystać ze źródeł informacji na temat religii; 8) wytwarzać i nabywać przedmioty potrzebne do celów kultu i praktyk 


\section{- Kodeks karny wykonawczy - ustawa z dnia 6 czerwca 1997 r. ${ }^{30}$,}

religijnych oraz korzystać z nich; 9) wytwarzać, nabywać i posiadać artykuły potrzebne do przestrzegania reguł religijnych; 10) wybrać stan duchowny lub zakonny; 11) zrzeszać się w organizacjach świeckich w celu realizacji zadań wynikających z wyznawanej religii bądź przekonań w sprawach religii; 12) otrzymać pochówek zgodny z wyznawanymi zasadami religijnymi lub z przekonaniami w sprawach religii”. Art. 4: „1. Prawo określone w art. 2 pkt 2 oraz prawo do posiadania i korzystania z przedmiotów potrzebnych do uprawiania kultu i praktyk religijnych przysługują również osobom: 1) pełniącym służbę wojskową lub zasadniczą służbę w obronie cywilnej; 2) przebywającym w zakładach służby zdrowia i opieki społecznej oraz dzieciom i młodzieży na krajowych koloniach i obozach organizowanych przez instytucje państwowe; 3) przebywającym w zakładach karnych, poprawczych i wychowawczych oraz aresztach śledczych, ośrodkach przystosowania społecznego oraz schroniskach dla nieletnich".

${ }^{30}$ Dz.U. Nr 90, poz. 557 z późn. zm. „Kodeks karny wykonawczy reguluje precyzyjnie korzystanie osadzonych z prawa do wolności religijnej oraz gwarantuje udział w wykonywaniu kar, środków karnych, zabezpieczających i zapobiegawczych, w szczególności związanych z pozbawieniem wolności kościołów i innych związków wyznaniowych. Art. 38. stanowi m.in. o udziale przedstawicieli społeczeństwa w wykonywaniu kar, w tym kościołów i związków wyznaniowych, których celem działalności jest przede wszystkim zaspokajanie potrzeb religijnych człowieka poprzez posługi religijne i odprawianie nabożeństw. Kościoły i związki wyznaniowe mogą uczestniczyć przede wszystkim w świadczeniu pomocy skazanym, byłym skazanym oraz ich rodzinom, jak też w resocjalizacji skazanych. Art. 102. określa prawa skazanych, w tym prawo do korzystania z wolności religijnej (zawarte w pkt 3), współdziałania z odpowiednimi stowarzyszeniami, organizacjami i instytucjami oraz kościołami i związkami wyznaniowymi (pkt 8). Art. 106 szczegółowo normuje realizację prawa do wolności religijnej, określając zakres i tryb korzystania z tego prawa. Zakres tego prawa obejmuje m.in.: wykonywanie praktyk religijnych, korzystanie z posług religijnych, bezpośrednie uczestnictwo w nabożeństwach odprawianych w zakładach karnych w dni świąteczne, słuchanie (i oglądanie) nabożeństw transmitowanych przez środki masowego przekazu, posiadanie niezbędnych książek, pism i przedmiotów potrzebnych do wykonywania praktyk religijnych. Inne uprawnienia skazanych wiążące się z wyznawaną przez nich religią i posiadające wymiar społeczny, to możliwość uczestniczenia w prowadzonym w zakładzie karnym nauczaniu religii, prawo do działalności charytatywnej lub społecznej, prawo do kontaktów z duchownymi wyznania, do którego skazany należy. Art. 109. zawiera m.in. możliwość uwzględnienia wymogów religijnych i kulturowych w żywieniu skazanych. Art. 135. zobowiązuje administrację jednostek penitencjarnych do stwarzania odpowiednich warunków spędzania czasu wolnego oraz określa pewne minimum urządzeń i możliwości, jakie w zakładzie karnym należy zapewnić w celu prowadzenia działalności kulturalnooświatowej. Art. 136. § 1 ustanawia podstawy do rozwijania działalności społecznej wśród skazanych, jak też nawiązywania przez skazanych kontaktów z instytucjami i stowarzyszeniami społecznymi”, http://www.edwi.pl/wp-content/uploads/2010/11/ Podstawy-prawne-dzialalnosci-kosciolow.pdf, [dostęp: 12.01.2016]. Zob. także Nikołajew, „Miejsce duszpasterstwa penitencjarnego", 382-385. 
- Ustawa z dnia 26 kwietnia 1996 r. o Służbie Więziennej ${ }^{31}$,

- Rozporządzenie Prezesa Rady Ministrów z dnia 1 grudnia 2003 r. w sprawie szczegółowego zakresu i trybu uczestnictwa podmiotów w wykonywaniu kar, środków karnych, zabezpieczających i zapobiegawczych, a także społecznej kontroli nad ich wykonywaniem ${ }^{32}$,

- Rozporządzenie Ministra Sprawiedliwości z dnia 25 sierpnia 2003 r. w sprawie regulaminu organizacyjno-porządkowego wykonywania kary pozbawienia wolności ${ }^{33}$,

- Rozporządzenie Ministra Sprawiedliwości z dnia 25 sierpnia 2003 r. w sprawie regulaminu organizacyjno-porządkowego wykonywania tymczasowego aresztowania ${ }^{34}$,

- Rozporządzenie Ministra Sprawiedliwości z dnia 2 września 2003 r. w sprawie szczegółowych zasad wykonywania praktyk religijnych i korzystania $\mathrm{z}$ posług religijnych $\mathrm{w}$ zakładach karnych i aresztach śledczych ${ }^{35}$.

${ }^{31}$ Dz.U. Nr 61, poz. 283. „Wśród podstawowych zadań Służby wymienia zapewnienie osobom skazanym na karę pozbawienia wolności lub tymczasowo aresztowanym przestrzegania ich praw, a zwłaszcza humanitarnych warunków, poszanowania godności, opieki zdrowotnej i religijnej”, Włodzimierz Głuch, „Struktura duszpasterstwa więziennego”, w: Duszpasterstwo więzienne w pracy penitencjarnej, red. Jan Świtka, Małgorzata Kuć (Lublin: Towarzystwo Naukowe KUL, 2007), 51.

${ }^{32}$ Dz.U. Nr 211, poz. 2051. Rozporządzenie to ,reguluje uczestnictwo stowarzyszeń, fundacji, organizacji i instytucji oraz Kościołów i innych związków wyznaniowych jak również osób godnych zaufania w wykonywaniu kar, środków karnych, zabezpieczających i zapobiegawczych poprzez m.in. prowadzenie działalności kulturalnej, oświatowej i sportowej wobec skazanych”, Głuch, „Struktura duszpasterstwa więziennego”, 51.

${ }^{33}$ Dz.U. Nr 152, poz. 1493.

${ }^{34}$ Dz.U. Nr 152, poz. 1494. Oba regulaminy zawierają regulacje dotyczące korzystania przez osadzonych z prawa do wolności religijnej.

${ }^{35}$ Dz.U. Nr 159, poz. 1546. Rozporządzenie to określa udział duchownych związków wyznaniowych wykonujących posługi religijne na terenie zakładów karnych i aresztów śledczych w ustalaniu porządku wewnętrznego w tym zakresie, ,reguluje wykonywanie indywidualnych posług religijnych”, ,określa podstawę zawarcia umowy o pełnienie funkcji kapelana” oraz „obliguje dyrektora zakładu do podejmowania niezbędnych czynności w celu zapewnienia odpowiednich warunków do wykonywania praktyk i posług religijnych oraz korzystania z tych posług, a także zasięgania opinii kapelana w sprawie organizacji posług religijnych”, Głuch, „Struktura duszpasterstwa więziennego”, 52. 
Przepisy te zobowiązują kierownictwa jednostek penitencjarnych do aktywnej realizacji prawa osadzonych do korzystania z pociechy religijnej i uczestnictwa w praktykach religijnych ${ }^{36}$. Uwzględnić należy także zbiór przepisów - rangi międzynarodowej i ustawowej - gwarantujących kościołom i związkom wyznaniowym prawo do sprawowania posług duszpasterskich. Zalicza się do nich przede wszystkim Konkordat między Stolicą Apostolską i Rzecząpospolitą Polską, podpisany w Warszawie dnia 28 lipca 1993 r. $^{37}$ oraz szereg ustaw o stosunku państwa do kościołów i związków wyznaniowych, których stosunki z państwem uregulowane są ustawami partykularnymi. Jak wskazuje A. Mezglewski: „Przepisy ustaw indywidualnych zawierają gwarancje wyznaczania przez właściwe władze poszczególnych związków wyznaniowych duchownych (kapelanów) pełniących posługi religijne w tych zakładach" "38. W ustawach: z dnia 17 maja 1989 r. o stosunku Państwa do Kościoła Katolickiego w Rzeczypospolitej Polskiej ${ }^{39}$ oraz

36 Tamże.

${ }^{37}$ Dz.U. Nr 51, poz. 318. Art. 17.1. „Rzeczpospolita Polska zapewnia warunki do wykonywania praktyk religijnych i korzystania z posług religijnych osobom przebywającym w zakładach penitencjarnych, wychowawczych, resocjalizacyjnych oraz opieki zdrowotnej i społecznej, a także w innych zakładach i placówkach tego rodzaju. 2. Osobom, o których mowa w ustępie 1, zapewnia się w szczególności możliwość uczestniczenia we Mszy św. w niedziele i święta oraz w katechizacji i rekolekcjach, a także korzystania z indywidualnych posług religijnych w zgodzie z celami pobytu tych osób w zakładach wskazanych w ustępie 1. 3. Dla realizacji uprawnień osób, o których mowa w ustępie 1, biskup diecezjalny skieruje kapelanów, z którymi odpowiednia instytucja zawrze stosowną umowę".

Przepisy konkordatowe nie zawierają w ogóle jakichkolwiek nakazów zatrudniania kapelanów więziennych. Sprawy te są pozostawione stosownym instancjom państwowym. Konkordat zatem konkretyzuje w tej mierze przepisy ustawy z dnia 17 maja 1989 r. o stosunku Państwa do Kościoła katolickiego w RP (Dz.U. Nr 29, poz. 154 z późn. zm.). Zob. Beata Ratajczak, „Duszpasterstwo więźniów, osób tymczasowo aresztowanych i nieletnich przestępców", w: Prawo wyznaniowe, red. Henryk Misztal, Piotr Stanisz (Lublin: Wydawnictwo Diecezjalne w Sandomierzu, 2003); 329, Aneta Abramowicz, „Duszpasterstwo w instytucjach penitencjarnych a zasada równouprawnienia związków wyznaniowych", w: Wolność sumienia i religii osób pozbawionych wolności. Aspekty prawne i praktyczne, red. Jerzy Nikołajew, Konrad Walczuk, (Warszawa: Wydawnictwo Unitas, 2016), 138.

${ }^{38}$ Artur Mezglewski, ,Działalność związków wyznaniowych w sferze publicznej”, w: Artur Mezglewski, Henryk Misztal, Piotr Stanisz, Prawo wyznaniowe (Warszawa: Wydawnictwo C.H. Beck, 2011), 211.

${ }^{39}$ Art. 32.1. Osoby tymczasowo aresztowane mogą wykonywać praktyki religijne i uczestniczyć we Mszy św. transmitowanej przez środki masowego przekazywania oraz, za 


\section{z dnia 4 lipca 1991 r. o stosunku Państwa do Polskiego Autokefaliczne-} go Kościoła Prawosławnego ${ }^{40}$ znajdujemy ponadto ,przepisy zobowiązujące kierowników tych zakładów do zawierania umów w sprawie nieodpłatnego wykonywania obowiązków kapelana z duchownymi, skierowanymi przez biskupa diecezjalnego"41.

\section{Jak wskazuje A. Abramowicz po dokonaniu szczegółowej analizy obowiązujących w naszym kraju przepisów prawnych dotyczących}

zgodą organu, do którego dyspozycji pozostają, korzystać z indywidualnej posługi religijnej. 2. Osobom skazanym zapewnia się możliwość wykonywania praktyk religijnych, korzystania z posług religijnych oraz uczestniczenia we Mszy św. odprawianej w niedziele i święta $\mathrm{w}$ odpowiednio przystosowanym pomieszczeniu w zakładzie, w którym przebywają. Osobom, które nie mogą uczestniczyć we Mszy św. odprawianej na terenie zakładu, należy zapewnić możność wysłuchania Mszy św. transmitowanej przez środki masowego przekazywania. 3. Nieletnim przebywającym w zakładach poprawczych i schroniskach dla nieletnich zapewnia się możliwość wykonywania praktyk religijnych, korzystania z katechizacji i posług religijnych, uczestniczenia we Mszy św. w niedziele i święta. Nieletnim, którzy nie mogą uczestniczyć we Mszy św., należy zapewnić możność wysłuchania Mszy św. transmitowanej przez środki masowego przekazywania. 4. W celu realizacji uprawnień osób wymienionych w ust. 1-3 kierownicy odpowiednich zakładów zawierają umowy w sprawie nieodpłatnego wykonywania obowiązków kapelana z duchownymi skierowanymi przez biskupa diecezjalnego.

${ }^{40}$ Dz.U. Nr 66, poz. 287 z późn. zm. Art. 28.1. Osoby tymczasowo aresztowane mogą wykonywać praktyki religijne i wysłuchiwać nabożeństw transmitowanych przez środki masowego przekazywania oraz, za zgodą organu, do którego dyspozycji pozostają, korzystać z indywidualnych posług religijnych. 2. Osobom skazanym zapewnia się możliwość wykonywania praktyk religijnych, korzystania z posług religijnych oraz uczestniczenia w nabożeństwach odprawianych w niedziele i święta prawosławne w odpowiednio przystosowanym pomieszczeniu w zakładzie, w którym przebywają. Osobom, które nie mogą uczestniczyć w odprawianych na terenie zakładu nabożeństwach, należy zapewnić, w miarę potrzeby, w oddzielnych pomieszczeniach, możliwość wysłuchania nabożeństw transmitowanych przez środki masowego przekazywania. 3. Nieletnim przebywającym w zakładach poprawczych i schroniskach dla nieletnich zapewnia się możliwość wykonywania praktyk religijnych, korzystania z katechizacji i posług religijnych, uczestniczenia w Liturgii Świętej w niedziele i święta prawosławne. Nieletnim, którzy nie mogą uczestniczyć w Liturgii Świętej, należy zapewnić, w miarę potrzeby, w oddzielnych pomieszczeniach, możliwość wysłuchania nabożeństw transmitowanych przez środki masowego przekazywania. 4. W celu realizacji uprawnień osób wymienionych w ust. 1-3 kierownicy odpowiednich zakładów zawierają umowy w sprawie nieodpłatnego wykonywania obowiązków kapelana z duchownymi skierowanymi przez biskupa diecezjalnego. Zob. także Małgorzata Winiarczyk-Kossakowska, Ustawy III Rzeczypospolitej o stosunku Państwa do kościołów chrześcijańskich (Warszawa: Dom Wydawniczy „Elipsa”, 2004), 119.

${ }^{41}$ Mezglewski, „Działalność związków wyznaniowych”, 211. 
omawianej w niniejszym tekście materii: „[...] wszystkie związki wyznaniowe o uregulowanej sytuacji prawnej mają prawo do organizowania posług duszpasterskich w zakładach penitencjarnych. Brak jest [...] w tym zakresie przejawów naruszenia konstytucyjnej zasady równouprawnienia związków wyznaniowych" ${ }^{42}$. W pełni akceptuję ten pogląd.

Wydaje się, że obecnie należałoby zbadać, jak powyżej przedstawione uprawnienia osób pozbawionych wolności są realizowane przez polskie władze więzienne i czy wszystkie zainteresowane posługą duszpasterską wśród więźniów związki wyznaniowe mają możliwość jej nieskrępowanego wypełniania, a zatem - czy konstytucyjna zasada równouprawnienia kościołów i innych związków wyznaniowych funkcjonuje w życiu codziennym polskiego więziennictwa. Zaznaczyć należy, że podstawę do badań stanowią sprawozdania okręgowych inspektoratów służby więziennej z roku $2008^{43}$, gdyż pozyskanie aktualniejszych okazało się zadaniem ponad moje siły. Jestem jednak przekonany, że obraz który wyłania się z ich analizy odpowiada realiom pierwszej połowy roku 2016, wyjąwszy zapewne kwestie dotyczące liczby etatów kapelańskich, która wydaje się być najbardziej płynna. W tekście nie poruszałem problemów związanych z organizacją stałych struktur duszpasterstwa więziennego (naczelny kapelan więziennictwa, rada główna duszpasterstwa więziennego, statut duszpasterstwa więziennego) mających koordynować jego prace i stanowić dlań pewne ramy organizacyjne na szczeblu krajowym. Skonstruowanie spójnych wypowiedzi na ten temat zakłada według mnie posiadanie orientacji w specjalistycznej dokumentacji i osobistego doświadczenia z zakresu funkcjonowania struktur więziennictwa, których to sprawności nie udało mi się na razie pozyskać w stopniu wystarczającym.

${ }^{42}$ Abramowicz, ,Duszpasterstwo w instytucjach penitencjarnych”, 136-137.

${ }^{43}$ Wszystkie poniższe dane dotyczące funkcjonowanie duszpasterstw więziennych w poszczególnych okręgowych inspektoratach służby więziennej w Polsce zaczerpnięto z obszernych tablic - aneksów do maszynopisu książki Jerzego Nikołajewa, Duszpasterstwo więzienne. Tradycje - teraźniejszość - perspektywy (Lublin: 2008), mps w posiadaniu autora. 
$\mathrm{Na}$ terenie aresztów śledczych (dalej AŚ) w Białymstoku, Giżycku, Hajnówce, Suwałkach i Ostrołęce oraz zakładów karnych (dalej ZK) w Białymstoku, Czerwonym Borze, i Grądach-Woniecku posługę duchowną sprawowali przedstawiciele Kościoła Rzymskokatolickiego, Muzułmańskiego Związku Religijnego w Rzeczypospolitej Polskiej, Kościoła Zielonoświątkowego, Kościoła prawosławnego i Świadków Jehowy.

Kapelani katoliccy zatrudnieni są w łącznym wymiarze 4,5 etatów, prawosławni - 1 etatu, duchowni pozostałych związków wyznaniowych sprawują swe funkcje nieodpłatnie.

W jednostkach penitencjarnych OISW w Białymstoku pracowali także wolontariusze świeccy (osoby nie będące kapelanami) reprezentujący Kościół Rzymskokatolicki (Bractwo Więzienne, ruch Comunione e Liberazione, Odnowa w Duchu Świętym, ministranci, schola). Organizują oni przede wszystkim spotkania ewangelizacyjne dla grup więźniów liczących od kilku do kilkudziesięciu osób.

\section{OKRĘGOWY INSPEKTORAT SŁUŻBY WIĘZIENNEJ W BYDGOSZCZY}

Kapelani rzymskokatoliccy pracowali we wszystkich jednostkach na terenie Inspektoratu (AŚ w Bydgoszczy, Chełmnie, Chojnicach, Inowrocławiu i Toruniu oraz ZK w Bydgoszczy-Fordonie, Czersku, Grudziądzu, Koronowie, Potulicach i Włocławku). Świadkowie Jehowy byli obecni w aresztach śledczych i zakładach karnych w Bydgoszczy, Chojnicach, Inowrocławiu, Toruniu, Koronowie i Włocławku, adwentyści (Kościół Adwentystów Dnia Siódmego) - tylko w Inowrocławiu, duchowni Kościoła Ewangelicko-Metodystycznego - tylko w Bydgoszczy, Kościoła Ewangelicko-Augsburskiego - tylko w Grudziądzu. Pastor i diakoni Kościoła Zielonoświątkowego posługiwali w Czersku, Grudziądzu, Koronowie i Włocławku. Przedstawicielka Kościoła Chrześcijan Baptystów ze zboru w Ostródzie posługiwała w ZK w Grudziądzu, gdzie duszpasterzował także przedstawiciel Kościoła Ewangelicko-Augsburskiego. Świadkowie Jehowy funkcjo- 
nowali natomiast w jednostkach w Bydgoszczy, Chojnicach, Inowrocławiu, Toruniu, Koronowie, Potulicach i Włocławku.

Kapelani katoliccy zatrudnieni w inspektoracie bydgoskim zajmowali łącznie 4,5 etatu. Przedstawiciele innych wspólnot religijnych wypełniali swe obowiązki na podstawie ,umów o świadczenie posług religijnych" lub byli zatrudniani w inny, nie wykazany w materiale źródłowym, sposób.

W ramach wolontariatu z osobami pozbawionymi wolności pracowali członkowie Kościoła Rzymskokatolickiego (Fundacja Instytut św. Brata Alberta, Bractwo Więzienne, Stowarzyszenie na Rzecz Bezdomnych Dom Modlitwy „Agape”, klerycy Wyższego Seminarium Duchownego w Toruniu, Odnowa w Duchu Świętym), Świadków Jehowy i Świeckiego Ruchu Misyjnego „Epifania”.

\section{OKREGOWY INSPEKTORAT SŁUŻBY WIEZZIENNEJ W GDAŃSKU}

W każdej z jednostek należących do tego inspektoratu (AŚ Gdańsk, Elbląg, Starogard Gdański i Wejherowo, ZK Sztum, Malbork, Kwidzyn, Gdańsk i Braniewo) funkcjonowali kapelani rzymskokatoliccy, prawosławni pracowali w AŚ w Gdańsku, Wejherowie, ZK w Sztumie, Gdańsku, a Świadkowie Jehowy w AŚ w Gdańsku, Elblągu, Wejherowie, ZK w Malborku, Sztumie, Gdańsku i Braniewie. Przedstawiciel Kościoła Chrześcijan „Nowe Przymierze” pracował w AŚ w Gdańsku, adwentyści duszpasterzowali tamże oraz w ZK w Sztumie, zielonoświątkowcy w AŚ w Gdańsku i Wejherowie, w ZK w Sztumie, Kwidzynie, Gdańsku, baptyści w ZK w Sztumie i Malborku. W AŚ w Gdańsku pracował Selim Chazbijewicz, przedstawiciel Muzułmańskiego Związku Religijnego w RP.

Ogółem w inspektoracie gdańskim kapelani katoliccy zajmowali 5 etatów, duchowny prawosławny był zatrudniony w AŚ w Gdańsku na pół etatu. Pozostali duchowni wykonywali swe czynności nieodpłatnie. Stosunkowo niewielkie było zaangażowanie świeckich. W ZK w Sztumie działała Misja Więzienna FYLAKE należąca do Kościoła Chrześcijan Wiary Ewangelicznej, w ZK w Gdańsku Wspólnota Taize, zaś w A Ś w Elblągu - Odnowa w Duchu Świętym. 
$\mathrm{Na}$ terenie inspektoratu praktycznie we wszystkich jednostkach obecni byli duszpasterze rzymskokatoliccy. Świadkowie Jehowy opiekę duchową nad pozbawionymi wolności sprawowali w AŚ w BielskuBiałej, Bytomiu, Mysłowicach, Zabrzu, ZK w Jastrzębiu Zdroju i Zabrzu. Pastorzy zielonoświątkowi pracowali w AŚ w Bielsku-Białej, Tarnowskich Górach, ZK w Wojkowicach i Zabrzu, adwentyści w AŚ w Bielsku-Białej, ZK w Cieszynie i Zabrzu. Kościół EwangelickoAugsburski był reprezentowany w AŚ w Częstochowie, Sosnowcu, ZK w Raciborzu i Zabrzu, Polski Autokefaliczny Kościół Prawosławny w AŚ w Katowicach, Związek Wyznaniowy Gedeonitów w ZK Herby i Zabrze, Kościół Wolnych Chrześcijan w ZK Zabrze, podobnie jak Kościół Pentakostalny, Kościół Zborów Chrystusowych i Kościół Chrześcijan Baptystów.

W inspektoracie katowickim kapelani rzymskokatoliccy zajmowali 3,25 etatu, duszpasterz prawosławny - 0,25 etatu, ewangelickoaugsburski - 1 etat (ks. Piotr Janik, Naczelny Kapelan Ewangelickiego Duszpasterstwa Więziennego ${ }^{44}$, pracujący w ZK w Zabrzu).

Zaangażowani w duszpasterstwo więzienne wolontariusze świeccy byli członkami Kościoła Rzymskokatolickiego (Legion Maryi, Odnowa w Duchu Świętym, Stowarzyszenie Rodzin Katolickich Diecezji Gliwickiej, Bractwo Więzienne), Towarzystwa „Strażnica” w Sosnowcu oraz Chrześcijańskiego Stowarzyszenia Pomocy Resocjalizacyjnej „Fileo” z Cieszyna.

W tym inspektoracie we wszystkich jednostkach pracowali kapelani rzymskokatoliccy (AŚ w Koszalinie, Słupsku, Złotowie, ZK w Koszalinie, Czarnem, Wierzchowie, Szczecinku i Starym Bornem). Jeden kapelan prawosławny obsługiwał AŚ i ZK w Koszalinie, podobnie jak duchowny zielonoświątkowy. Ponadto kościół ten miał swego

${ }^{44}$ Zob. http://www.edwi.pl/?page_id=2, [dostęp: 16.02.2016]. 
duszpasterza w ZK w Czarnem. Świadkowie Jehowy funkcjonowali w AŚ w Koszalinie, w ZK w Czarnem i Starym Bornem, w Szczecinku i Koszalinie, zaś ewangelicy w AŚ w Słupsku, w ZK w Starym Bornem, Czarnem i Koszalinie. Świecki Ruch Misyjny „Epifania” miał swego przedstawiciela w ZK w Czarnem.

W inspektoracie koszalińskim kapelani rzymskokatoliccy zatrudnieni byli na 3,2 etatu, a jeden kapelan prawosławny na 0,25 etatu. Inni duchowni sprawowali posługi nieodpłatnie.

Świeccy ochotnicy działali w ramach Bractwa Więziennego, Bractwa Modlitwy i Trzeźwości „Arka”, Instytutu św. Brata Alberta, protestanckiej Fundacji „Głos Ewangelii”. Ponadto indywidualnie spotykali się z pensjonariuszami zakładów przedstawiciele Kościoła Adwentystów Dnia Siódmego, Świadkowie Jehowy i Świeckiego Ruchu Misyjnego „Epifania”.

OKRĘGOWY INSPEKTORAT SŁUŻBY WIĘZIENNEJ W KRAKOWIE

We wszystkich jednostkach przynależnych do inspektoratu krakowskiego pracowali duszpasterze katoliccy. Zielonoświątkowcy obecni byli w ZK w Wadowicach i w Nowym Sączu, Świadkowie Jehowy w ZK w Wadowicach, Pińczowie, Nowym Wiśniczu, Tarnowie, Tarnowie-Mościcach, Krakowie-Nowej Hucie, adwentyści w ZK w Wadowicach, Pińczowie, Nowym Wiśniczu, chrześcijanie wiary ewangelicznej w ZK w Pińczowie a prawosławni w ZK w Pińczowie i AŚ w Kielcach. Kapłan polskokatolicki duszpasterzował w areszcie kieleckim, przedstawiciel Świeckiego Ruchu Misyjnego „Epifania” w ZK w Nowym Wiśniczu i w Krakowie-Nowej Hucie, a działacz Związku Buddystów Zen Bodhidharma ${ }^{45}$ - w ZK w Tarnowie.

Kapelani rzymskokatoliccy zatrudnieni byli łącznie na 2,5 etatach, duchowny prawosławny - na 0,25 etatu. W innych przypadkach posługi wykonywane były nieodpłatnie.

Duchownych wspierali wolontariusze świeccy reprezentujący Kościół Rzymskokatolicki (Stowarzyszenie Rodzin Katolickich, alumni Wyższego Seminarium Duchownego w Tarnowie, Bractwo

${ }^{45} \mathrm{http}: / / w w w . b u d d y z m z e n . p l /$, [dostęp 22.02.2016]. 
Więzienne i grupa ewangelizacyjna Ruchu „Światło-Życie”), Kościół Zielonoświątkowy, Świadków Jehowy, Kościół Adwentystów Dnia Siódmego, Kościół Chrześcijan Wiary Ewangelicznej, Kościół Chrześcijański „Wieczernik”" Świecki Ruch Misyjny „Epifania” oraz wspólnoty ewangelickie.

\section{OKRĘGOWY INSPEKTORAT SŁUŻBY WIĘZIENNEJ W LUBLINIE}

We wszystkich jednostkach penitencjarnych tego inspektoratu obecni byli kapelani rzymskokatoliccy i prawosławni. Grekokatolicy posługiwali w ZK w Chełmie, Zamościu, AŚ w Krasnymstawie i Lublinie, zielonoświątkowcy w ZK w Chełmie i w ZK w Zamościu, polskokatolicy w ZK w Chełmie, baptyści w ZK w Chełmie, w AŚ w Krasnymstawie, adwentyści w ZK w Chełmie i w ZK w Zamościu, Świadkowie Jehowy w ZK w Hrubieszowie, we Włodawie i w Zamościu oraz w AŚ w Krasnymstawie. Duszpasterz polskokatolicki pracował w ZK w Chełmie, przedstawiciel Kościoła Bożego w Chrystusie w ZK w Hrubieszowie, pani pastor ze świdnickiego Kościoła Chrześcijańskiego „Nowe Życie” w AŚ w Krasnymstawie i w ZK we Włodawie a duszpasterz Kościoła Chrześcijan Wiary Ewangelicznej - w ZK we Włodawie.

Duchowni rzymskokatoliccy zajmowali w jednostkach inspektoratu lubelskiego 2,25 etatu, prawosławni - 2,75 etatu, a grekokatoliccy 0,25 etatu. Pozostali kapelani pracowali nieodpłatnie.

Świeccy wolontariusze wspomagający posługę kapelanów reprezentowali Kościół Rzymskokatolicki (Odnowa w Duchu Świętym, Legion Maryjny, Wspólnota RuAH), prawosławny (psalmista), Świadków Jehowy, Kościół Zielonoświątkowy.

Podobnie jak w innych inspektoratach, także w inspektoracie łódzkim we wszystkich jednostkach duszpasterzowali kapelani rzymskokatolic-

\footnotetext{
${ }^{46} \mathrm{http}: / / w w w . w i e c z e r n i k . p l /$, [dostęp 22.02.2016].
} 
cy. Prawosławni byli reprezentowani w ZK nr 1 w Łodzi, ZK w Płocku, AŚ w Piotrkowie Trybunalskim, Świadkowie Jehowy w ZK nr 2 w Łodzi, ZK w Łowiczu, Garbalinie, Sieradzu i Płocku, w AŚ w Piotrkowie Trybunalskim. Przedstawiciele Kościoła Zielonoświątkowego pracowali w ZK nr 2 w Łodzi i w AŚ w Piotrkowie Trybunalskim, kapelani prawosławni w ZK w Płocku i w AŚ w Piotrkowie Trybunalskim. Pastor adwentystyczny posługiwał w AŚ w Piotrkowie Trybunalskim i w ZK w Płocku, przedstawiciel Kościoła Chrześcijan Baptystów pracował w ZK w Łowiczu, Centrum Biblijnego „Jezus jest Panem”47 - w ZK Łowicz, Świeckiego Ruchu Misyjnego „Epifania” - w ZK w Łowiczu i Płocku, Kościoła Chrześcijańskiego „Jezus żyje” - w ZK Garbalin, Kościoła Zborów Chrystusowych - w ZK w Płocku, Kościoła Ewangelicko-Augsburskiego i Kościoła Ewangelicko-Reformowanego oraz Kościoła Chrześcijan Dnia Sobotniego - także w ZK w Płocku.

Kapelani rzymskokatoliccy zajmowali 4,25 etatów. Przedstawiciele innych związków wyznaniowych swe zadania wykonywali społecznie.

Wolontariusze świeccy uzupełniający posługę kapelanów reprezentowali Kościół Rzymskokatolicki (Odnowa w Duchu Świętym, Wspólnota Krwi Chrystusa, Legion Maryi, alumni Wyższego Seminarium Duchownego o.o. Franciszkanów w Łodzi-Łagiewnikach) oraz większość wspólnot wyznaniowych zaangażowanych w dzieło duchowego wsparcia osób pozbawionych wolności na terenie inspektoratu łódzkiego.

\section{OKRĘGOWY INSPEKTORAT SŁUŻBY WIĘZIENNEJ W OLSZTYNIE}

Kapelani rzymskokatoliccy byli obecni we wszystkich jednostkach penitencjarnych inspektoratu olsztyńskiego. Ewangelicy pracowali w ZK w Barczewie, zielonoświątkowcy także posługiwali w tej jednostce oraz w AŚ w Bartoszycach, Szczytnie i Olsztynie, ZK w Iławie i Kamińsku, prawosławni w ZK w Barczewie i Kamińsku, Świadkowie Jehowy w ZK w Barczewie, Iławie, Kamińsku, AŚ w Bartoszycach i w Szczytnie. Kościół Adwentystów Dnia Siódmego miał swego

${ }^{47} \mathrm{https} / /$ pl.wikipedia.org/wiki/Centrum_Biblijne_\%E2\%80\%9EJezus_Jest_Panem $\%$ E2\%80\%9D, [dostęp: 22.02.2016]. 
przedstawiciela w ZK w Iławie, zaś Kościół Chrześcijan Baptystów w ZK w Kamińsku.

Kapelani rzymskokatoliccy zajmowali 6,7 etatu, ewangelicy - 0,5 etatu, prawosławni - 0,5 etatu, zielonoświątkowcy - 0,25 etatu.

Wolontariat świecki wywodził się z Kościoła Rzymskokatolickiego (Bractwo Więzienne, Ruch „Światło-Życie”), Świeckiego Ruchu Misyjnego „Epifania” i spośród Świadków Jehowy.

We wszystkich jednostkach penitencjarnych inspektoratu opolskiego pracowali kapelani rzymskokatoliccy. Świadkowie Jehowy obecni byli w ZK w Głubczycach, w Grodkowie, w Brzegu, w ZK nr 1 w Strzelcach Opolskich, w AŚ w Kędzierzynie-Koźlu i w Prudniku. Kościół Zielonoświątkowy miał swoich duszpasterzy w ZK w Kluczborku, Brzegu w ZK nr 1 w Strzelcach Opolskich i w AŚ w Kędzierzynie-Koźlu. Duszpasterze prawosławni posługiwali w ZK nr 1 i ZK nr 2 w Strzelcach Opolskich zaś pastor ewangelicko-augsburski - w ZK nr 2 w Strzelcach Opolskich.

$\mathrm{Na}$ etaty (w wymiarze 4,25) zatrudnieni byli jedynie kapelani rzymskokatoliccy. Pozostali świadczyli posługi nieodpłatnie.

Wolontariusze świeccy wywodzili się z Kościoła Zielonoświątkowego, Kościoła Rzymskokatolickiego (Bractwo Więzienne), Szkoły Zen Kwan Um ${ }^{48}$, Kościoła Adwentystów Dnia Siódmego, wspólnoty Świadków Jehowy, Świeckiego Ruchu Misyjnego „Epifania”, Chrześcijańskiego Stowarzyszenia Pomocy Resocjalizacyjnej „Fileo” ze Skoczowa, zboru chrześcijan z Grabowa nad Prosną.

W inspektoracie poznańskim we wszystkich jednostkach funkcjonowali kapelani rzymskokatoliccy. Duchowni prawosławni pracowali w AŚ

${ }^{48}$ http://www.zen.pl/, [dostęp: 23.02.2016]. 
w Lubsku, Poznaniu, Zielonej Górze, w ZK w Kaliszu i w Krzywańcu. Kapelani zielonoświątkowi byli obecni w AŚ w Lubsku, Poznaniu, Zielonej Górze i w Nowej Soli. Ponadto w ZK w Koziegłowach, w Rawiczu i we Wronkach. Międzynarodowe Stowarzyszenie Gedeonitów ${ }^{49}$ duszpasterzowało w AŚ w Lubsku i w Ostrowie Wielkopolskim, Świadkowie Jehowy w AŚ w Lubsku, Nowej Soli, Ostrowie Wielkopolskim, Poznaniu, Zielonej Górze, w ZK w Gębarzewie, w Kaliszu, Koziegłowach, Krzywańcu, Rawiczu i we Wronkach. Przedstawiciele Kościoła Chrześcijańskiego „Arka” ${ }^{50}$ byli aktywni w AŚ w Poznaniu, w Śremie i w ZK w Koziegłowach, Kościoła Chrześcijan Baptystów w AŚ w Śremie, Kościoła Bożego w Chrystusie ${ }^{51}$ w AŚ w Zielonej Górze, Świeckiego Ruchu Misyjnego „Epifania” w ZK w Rawiczu, grekokatolicy w AŚ w Zielonej Górze, a adwentyści w ZK we Wronkach.

Kapelani rzymskokatoliccy zatrudnieni byli ogółem na 3,03 etatu, prawosławni na 0,48 etatu, a duchowny zielonoświątkowy - na 0,5 etatu. Inne formy zatrudnienia kapelanów to ,umowy o wykonywanie posług religijnych”, bliżej nieokreślone ,porozumienia” lub wolontariat.

Działalność duszpasterską w jednostkach penitencjarnych prowadziły także osoby świeckie związane z Kościołem Rzymskokatolickim (Bractwo Więzienne, Odnowa w Duchu Świętym), wspólnotami Świadków Jehowy, Międzynarodowym Stowarzyszeniem Gedeonitów i Świeckim Ruchem Misyjnym „Epifania”.

\section{OKREGGWY INSPEKTORAT SŁUŻBY WIĘZIENNEJ W RZESZOWIE}

We wszystkich jednostkach tego inspektoratu pracowali kapłani rzymskokatoliccy. Duchowni prawosławni duszpasterzowali w AŚ w Sanoku, w ZK w Dębicy, Medyce, Przemyślu i Rzeszowie. Zielonoświątkowcy pracowali w ZK w Jaśle, Łupkowie i w Rzeszowie, Świadkowie Jehowy w ZK w Medyce, Przemyślu, Rzeszowie, przedstawi-

${ }^{49} \mathrm{https}: / /$ pl.wikipedia.org/wiki/Mi\%C4\%99dzynarodowe_Stowarzyszenie_Gedeonit\%C3\%B3w, [dostęp: 23.02.2016].

${ }^{50} \mathrm{http}: / / w w w . a r k a . o r g . p l /$, [dostęp: 23.02.2016].

${ }^{51} \mathrm{http}: / / \mathrm{kbwch} . \mathrm{pl} / \mathrm{index} . \mathrm{php}$, [dostęp: 23.02.2016]. 
ciel Kościoła Chrześcijan Wiary Ewangelicznej ${ }^{52}$ w ZK w Rzeszowie, Kościoła Adwentystów Dnia Siódmego w ZK w Medyce, a kościoła greckokatolickiego - w ZK w Uhercach i w Przemyślu.

Wszyscy kapelani rzymskokatoliccy $\mathrm{w}$ tym inspektoracie mieli łącznie 1,85 etatu, zielonoświątkowi - 0,1 etatu a prawosławni - 0,25 etatu. Wielu duchownych tych i pozostałych wyznań funkcjonowało jako wolontariusze.

Wolontariusze świeccy należeli do Kościoła Rzymskokatolickiego (Katolicki Ruch Antynarkotyczny „Karan”, Odnowa w Duchu Świętym, Krucjata Wyzwolenia Człowieka, Bractwo Więzienne, Apostolstwo Trzeźwości), wspólnoty Świadków Jehowy, Świeckiego Ruchu Misyjnego „Epifania”, Kościoła Adwentystów Dnia Siódmego (Stowarzyszenie Promocji Zdrowego Stylu Życia).

OKRĘGOWY INSPEKTORAT SŁUŻBY WIĘZIENNEJ W SZCZECINIE

We wszystkich jednostkach działalność duszpasterską prowadzili kapłani Kościoła Rzymskokatolickiego. Kościół Ewangelicznych Chrześcijan ${ }^{53}$ był reprezentowany w ZK w Nowogardzie i w Goleniowie, Świadkowie Jehowy w ZK w Nowogardzie, Stargardzie Szczecińskim, Gorzowie Wielkopolskim, Goleniowie, AŚ w Międzyrzeczu i Świnoujściu. Świecki Ruch Misyjny „Epifania” opiekował się osobami pozbawionymi wolności w ZK w Nowogardzie, podobnie jak Kościół Boży w Chrystusie. Kościół Chrześcijan Baptystów duszpasterzował w ZK w Nowogardzie i w AŚ w Świnoujściu, Kościół Adwentystów Dnia Siódmego w ZK w Nowogardzie i w Goleniowie, Kościół Chrześcijan Baptystów ${ }^{54}$ tylko w ZK w Nowogardzie, Kościół prawosławny tylko w ZK w Gorzowie Wielkopolskim, Kościół Zielonoświątkowy tamże i w ZK w Stargardzie Szczecińskim.

Kapelani rzymskokatoliccy zatrudnieni byli łącznie na 3 etaty. Pozostali pracowali nieodpłatnie (,charytatywnie”).

\footnotetext{
${ }^{52} \mathrm{http}: / / \mathrm{kchwe} . \mathrm{pl} /$, [dostęp: 23.02.2016].

${ }^{53} \mathrm{http}: / /$ www.kech.pl/, [dostęp: 24.02.2016].

${ }^{54} \mathrm{http}: / / w w w . b a p t y s c i . p l /$, [dostęp: 24.02.2016].
} 
Obok kapelanów działalność duszpasterską prowadziły osoby świeckie, wywodzące się z Kościoła Rzymskokatolickiego (m.in. Fundacja Św. Brata Alberta „Arka”), Kościoła Ewangelicznych Chrześcijan, wspólnot Świadków Jehowy, Świeckiego Ruchu Misyjnego „Epifania”, Kościoła Bożego w Chrystusie, Kościoła Adwentystów Dnia Siódmego, Kościoła Chrześcijan Baptystów, Misji Buddyjskiej „Trzy Schronienia”, Kościoła prawosławnego.

We wszystkich jednostkach penitencjarnych inspektoratu warszawskiego zatrudnieni byli kapelani rzymskokatoliccy. Duchowni prawosławni pracowali w AŚ w Warszawie-Białołęce, Warszawie-Grochowie, Warszawie-Mokotowie, Grójcu, Radomiu, w ZK w Siedlcach. Duszpasterze Kościoła Zielonoświątkowego funkcjonowali w AŚ w Warszawie-Białołęce, Warszawie-Mokotowie, Warszawie-Służewcu, w ZK w Siedlcach i w Warszawie-Białołęce, Świadkowie Jehowy w AŚ w Warszawie-Białołęce, Warszawie-Mokotowie, Warszawie-Służewcu, Radomiu, w ZK w Warszawie-Białołęce, Siedlcach i Żytkowicach. Kościół Ewangelicznych Chrześcijan posiadał swego przedstawiciela w AŚ w Warszawie-Mokotowie, podobnie jak Muzułmański Związek Religijny. Pastor adwentystyczny posługiwał tylko w ZK Siedlce.

Kapelani rzymskokatoliccy zajmowali 5,5 etatu, prawosławni - 3 etaty. Pozostali wykonywali swe zadania duszpasterskie nieodpłatnie.

Wolontariusze świeccy wspomagający działania kapelanów pochodzili z Kościoła Rzymskokatolickiego (m.in. Bractwo Więzienne, klerycy Wyższego Seminarium Duchownego w Warszawie), Kościoła Chrześcijan Wiary Ewangelicznej (Misja Więzienna „Fylake”), Międzynarodowego Stowarzyszenia Gedeonitów, wspólnot Świadków Jehowy, Kościoła Zielonoświątkowego.

OKRĘGOWY INSPEKTORAT SŁUŻBY WIĘZIENNEJ WE WROCŁAWIU

We wszystkich jednostkach penitencjarnych inspektoratu wrocławskiego zatrudnieni byli kapelani rzymskokatoliccy. Duchowni prawo- 
sławni posługiwali w AŚ we Wrocławiu, w Lubaniu, w ZK nr 1 we Wrocławiu i w Zarębie, ewangeliccy w AŚ we Wrocławiu i w ZK w Wołowie, baptystyczni w ZK nr 1 we Wrocławiu, a Świadkowie Jehowy w AŚ we Wrocławiu, Świdnicy, Jeleniej Górze, Lubaniu, Dzierżoniowie, w ZK w Głogowie, Oleśnicy, Strzelinie, Kłodzku, Zarębie, ZK nr 1 i nr 2 we Wrocławiu oraz Wołowie. Kapelani zielonoświątkowi byli obecni w AŚ w Jeleniej Górze, w Lubaniu, w ZK w Głogowie, Kłodzku, Zarębie, w ZK nr 2 we Wrocławiu i w Wołowie. Świecki Ruch Misyjny „Epifania” działał z ZK w Oleśnicy i w Wołowie oraz w ZK nr 1 we Wrocławiu. Stowarzyszenie Buddyjskie „Sangha Kanzeon" 55 funkcjonowało w ZK w Wołowie i w ZK nr 1 we Wrocławiu.

Kapelani rzymskokatoliccy zajmowali łącznie 4,85 etatów. Pozostali kapelani pracowali nieodpłatnie.

Świeccy wolontariusze, pracujący $\mathrm{w}$ jednostkach penitencjarnych inspektoratu wrocławskiego wywodzili się głównie z Kościoła Rzymskokatolickiego (Fundacja Instytut św. Brata Alberta, Bractwo Więzienne, Stowarzyszenie na Rzecz Bezdomnych Dom Modlitwy „Agape" 56 , Odnowa w Duchu Świętym, klerycy Wyższego Seminarium Duchownego we Wrocławiu), wspólnot Świadków Jehowy, Świeckiego Ruchu Misyjnego „Epifania”, Kościoła Zielonoświątkowego oraz Stowarzyszenia Buddyjskiego „Sangha Kanzeon”.

Działania podejmowane przez kapelanów więziennych wszystkich wyznań na terenie jednostek penitencjarnych podzielić można zasadniczo na cztery grupy: posługa sakramentalna (sprawowanie Mszy św., spowiedź, asystowanie przy zawieraniu małżeństw sakramentalnych, chrzty, bierzmowanie itp.), działalność katechetyczna (lekcje „religii”, koła biblijne, szeroko pojęta działalność edukacyjna w ramach doktryny związku wyznaniowego), działalność charytatywna (realizowana przez związki wyznaniowe, skierowana do osób osadzonych oraz reali-

\footnotetext{
${ }^{55} \mathrm{http}: / /$ www.kanzeon.pl/, [dostęp: 29.02.2016].

${ }^{56} \mathrm{http}: / / w w w . a g a p e . i n f o . p l /$, [dostęp: 29.02.2016].
} 
zowana przez osadzonych, a skierowana ku osobom spoza więziennych murów) oraz różnego typu działania kulturalno-edukacyjne realizowane przez kapelanów bądź za ich pośrednictwem (koncerty, kursy, konkursy artystyczne, pielgrzymki itp.).

Posługa sakramentalna kierowana była najczęściej do grup od kilku do kilkudziesięciu osadzonych, jej częstotliwość uzależniona była od zainteresowania przez nich okazywanego. Mogła mieć wymiar indywidualny (np. spowiedź) lub zbiorowy (Eucharystia). Czasami do tego typu działalności włączano rekolekcje lub dni skupienia przed większymi świętami religijnymi (Wielkanoc, Boże Narodzenie).

Nauczanie katechetyczne realizowane było dla grup liczących od 5 uczestników z różną częstotliwością. Przeprowadzano także kursy przedmałżeńskie i cykle przygotowań np. do przyjęcia sakramentu bierzmowania. W prowadzenie działań tego typu włączali się czasem wolontariusze świeccy, reprezentujący np. katolicką Odnowę w Duchu Świętym. W niektórych jednostkach praktykowano odwiedziny kolędowe w celach czy nabożeństwa drogi krzyżowej w okresie Wielkiego Postu.

W ramach „działalności charytatywnej” realizowano różnego rodzaju przedsięwzięcia. Było to np. porządkowanie cmentarzy różnych wyznań, zbiórki żywności dla rodzin patologicznych, udział w pielgrzymce autokarowej do Częstochowy i Góry Kalwarii, prace społeczne na rzecz diecezjalnego „Caritas” czy wybranej parafii, dostarczanie literatury religijnej dla osadzonych, przekazywanie dla nich paczek z okazji świąt, pomoc dla więźniarek w ciąży. W wielu jednostkach tego typu działalność nie była w ogóle prowadzona.

W zakresie ,zajęć nie związanych bezpośrednio z działalnością religijną, ale mających związek np. z moralnością itp." (określenie pochodzące $\mathrm{z}$ dokumentów OISW w Białymstoku) realizowano najróżniejsze działania, począwszy od spotkań „z ciekawymi ludźmi” i pielgrzymek do miejsc świętych, poprzez koncerty, funkcjonowanie kółek plastycznych, kursów językowych, aż do zwiedzania zabytków sakralnych i wydarzeń sportowych (mecze piłki nożnej z klerykami seminarium duchownego).

Ilość, różnorodność i jakość tych wszystkich działań wydaje się być uzależniona jedynie od potrzeb osadzonych, wrażliwości, inwen- 
cji i zaangażowania kapelanów oraz osób ich wspomagających. Oczywiście, pewną rolę odgrywały tutaj także możliwości logistyczno-materialne związku wyznaniowego, który reprezentował działający duszpasterz.

Także działania osób wspomagających duszpasterzy (,świeccy”) były bardzo różnorodne. Obejmowały różnego typu spotkania ewangelizacyjne, liturgiczne oprawy sprawowanych w jednostce sakramentów, prowadzenie audycji w radiowęźle, przygotowywanie symbolicznych poczęstunków dla uczestników ww. spotkań. Także projekcje filmów o tematyce religijnej, organizowanie koncertów, spotkania wigilijne dla dzieci osadzonych, przygotowywanie więźniów do przyjęcia sakramentów, udostępnianie księgozbioru parafialnego, animowanie grupy Anonimowych Alkoholików, a nawet pomoc mieszkaniową osobom zwolnionym z zakładu karnego.

Jak pisze J. Nikołajew: „Duszpasterstwo penitencjarne w sposób właściwy modeluje życie religijne osób pozbawionych wolności i pozostałe stosunki wewnętrzne panujące w społeczności więźniów. Utrwala przy tym wartości obiektywnie sprawdzone, nie gloryfikuje zła i przemocy ani postaw antyspołecznych. Traktowane jest w znaczeniu realizacji prawa osadzonych do swobodnego praktykowania wybranej przez siebie religii i korzystania z posług w tym zakresie ze strony uprawnionych osób" ${ }^{57}$. Z analizy wyżej przedstawionych sprawozdań okręgowych inspektoratów służby więziennej wynika, że taka diagnoza wysiłków kapelanów więziennych była powszechnie akceptowana w polskim więziennictwie [w roku 2008 - AS], zarówno jeśli chodzi o władze centralne, jak i dyrektorów poszczególnych jednostek penitencjarnych. Prawdą także jest, że dostęp do takiej posługi traktowany jest jako naturalne i bezdyskusyjne prawo osoby pozbawionej wolności. Działania duszpasterskie w jednostkach penitencjarnych realizuje

${ }^{57}$ Jerzy Nikołajew, „Specyfika duszpasterstwa więziennego w Polsce. Prezentacja badań własnych”, Teologia w Polsce 3/1 (2009): 153. 
wiele kościołów i związków wyznaniowych. Oczywiście, muszą być zainteresowane sprawowaniem posługi tego typu, muszą mieć wśród pensjonariuszy zainteresowanych wyznawców mogących brać udział w spotkaniach, muszą posiadać odpowiedni potencjał do prowadzenia działalności religijnej o charakterze z założenia ciągłym. Co oczywiste, „pociecha religijna” musi przyjmować formy niesprzeczne z obowiązującym prawem i normami współżycia społecznego. Po spełnieniu tych podstawowych warunków - jak się wydaje - działalność duszpasterska na terenie jednostki penitencjarnej staje się możliwa. Przyjmuje ona różne formy, różna jest częstotliwość kontaktów kapelanów z pensjonariuszami, różna skala zjawiska, czy to na terenie podległym konkretnemu inspektoratowi, czy w całym kraju. W różny sposób w działania duszpasterskie włączają się grupy wolontariuszy świeckich. Brak jednak oznak apriorycznego utrudniania czy uniemożliwiania jakiemukolwiek związkowi wyznaniowemu sprawowania posługi duszpasterskiej w jednostkach penitencjarnych.

Oczywiście, największy związek wyznaniowy w Polsce - Kościół rzymskokatolicki, działa praktycznie we wszystkich aresztach śledczych i zakładach karnych, a delegowani przezeń duchowni obsadzają najwięcej etatów kapelańskich ${ }^{58}$. Aby wprowadzić element równowagi - na uwagę zasługuje działalność duszpasterska przedstawicieli wspólnot Świadków Jehowy czy pastorów zielonoświątkowych, aktywnych w bardzo dużej liczbie placówek - pracujących zatem z pewnością także dla bardzo nielicznych grup współwyznawców. Takie pozorne nieregularności nie mają jednak w żadnym razie cech dyskryminacji. Jak wskazuje A. Abramowicz: „Należy je w tym przypadku nazwać dopuszczalnym różnicowaniem sytuacji prawnej związków wyznaniowych, które są zgodne z konstytucyjną zasadą równouprawnienia związków wyznaniowych"59.

${ }^{58}$ Zob. Abramowicz, „Duszpasterstwo w instytucjach penitencjarnych”, 140-141. Autorka przytacza za Jerzym Nikołajewem następujące liczby: kapelani Kościoła Rzymskokatolickiego ogółem zajmowali 60,28 etatu, Polskiego Autokefalicznego Kościoła Prawosławnego - 9,98 etatu, Kościoła Ewangelicko-Augsburskiego - 1,95 etatu, Kościoła Zielonoświątkowego - 0,75 etatu, Kościoła greckokatolickiego - 0,25 etatu. Kapelani należący do innych związków wyznaniowych wykonywali swe posługi nieodpłatnie. Stan ten dotyczy roku 2007.

${ }^{59}$ Tamże, 141. 
Reasumując powyższe rozważania stwierdzić należy, że zasada równouprawnienia kościołów i innych związków wyznaniowych w Polsce na przestrzeni ostatnich lat jest w sferze funkcjonowania duszpasterstw penitencjarnych w pełni zachowywana.

\section{BIBLIOGRAFIA}

Abramowicz, Aneta M. „Duszpasterstwo w instytucjach penitencjarnych a zasada równouprawnienia związków wyznaniowych". W: Wolność sumienia i religii osób pozbawionych wolności. Aspekty prawne i praktyczne, red. Jerzy Nikołajew, Konrad Walczuk. Warszawa: Wydawnictwo Unitas, 2016.

Boć, Jan. „Rozdział I. Rzeczpospolita”. W: Konstytucje Rzeczypospolitej Polskiej oraz komentarz do konstytucji RP z 1997 r., red. Jan Boć. Wrocław: Wydawnictwo Kolonia Limited, 1998.

Borecki, Paweł. „Zasada równouprawnienia wyznań w prawie polskim”. Studia z Prawa Wyznaniowego 10 (2007): 115-159.

Głuch, Włodzimierz. „Struktura duszpasterstwa więziennego”. W: Duszpasterstwo więzienne $w$ pracy penitencjarnej, red. Jan Świtka, Małgorzata Kuć. Lublin: Towarzystwo Naukowe KUL, 2007.

Góralski, Wojciech. Wstęp do prawa wyznaniowego. Płock: Płocki Instytut Wydawniczy, 2003.

Komadowska, Anna. „Prawo skazanego do korzystania z wolności religijnej a zasada humanitaryzmu". W: Wolność sumienia i religii osób pozbawionych wolności. Aspekty prawne i praktyczne, red. Jerzy Nikołajew, Konrad Walczuk, 115-127. Warszawa: Wydawnictwo Unitas, 2016.

Krukowski, Józef, Krzysztof Warchałowski. Polskie prawo wyznaniowe. Warszawa: Wydawnictwo Lexis Nexis, 2000.

Krukowski, Józef. Kościót i państwo. Podstawy relacji prawnych. Lublin: Redakcja Wydawnictw KUL, 2000.

Łyko, Zbigniew. „Wolność sumienia i wyznania w relacji: człowiek - kościoły - państwo". W: Podstawowe prawa jednostki i ich sadowa ochrona, red. Leszek Wiśniewski. Warszawa: Wydawnictwo Sejmowe, 1997.

Mezglewski, Artur. „Działalność związków wyznaniowych w sferze publicznej”. W: Artur Mezglewski, Henryk Misztal, Piotr Stanisz, Prawo wyznaniowe. Warszawa: Wydawnictwo C.H. Beck, 2011. 
Mezglewski, Artur, Henryk Misztal, Piotr Stanisz, Prawo wyznaniowe. Warszawa: Wydawnictwo C.H. Beck, 2005.

Misztal, Henryk. „Konstytucyjne podstawy polskiego prawa wyznaniowego". W: Prawo wyznaniowe, red. Henryk Misztal, Piotr Stanisz. Lublin: Wydawnictwo Diecezjalne w Sandomierzu, 2003.

Nikołajew, Jerzy. „Miejsce duszpasterstwa penitencjarnego w powrocie do wolności skazanych na podstawie Kodeksu Karnego Wykonawczego z 1997 roku i rozwiązań innych państw”. W: Stefan Lelental, Grażyna B. Szczygieł, X lat obowiąywania Kodeksu Karnego Wykonawczego. Białystok: Wydawnictwo Temida 2, 2009.

Nikołajew, Jerzy. Wolność sumienia i religii skazanych i tymczasowo aresztowanych. Lublin: Wydawnictwo KUL, 2011.

Nikołajew, Jerzy. „Specyfika duszpasterstwa więziennego w Polsce. Prezentacja badań własnych". Teologia w Polsce 3/1 (2009): 153.

Płatek, Monika. „Europejskie Reguły Więzienne a polskie prawo i praktyka penitencjarna". Studia Iuridica 34 (1997): 167-186.

Ratajczak, Beata. „Duszpasterstwo więźniów, osób tymczasowo aresztowanych i nieletnich przestępców". W: Prawo wyznaniowe, red. Henryk Misztal, Piotr Stanisz. Lublin: Wydawnictwo Diecezjalne w Sandomierzu, 2003.

Sitarz, Mirosław. „Zasada równouprawnienia kościołów i innych związków wyznaniowych”. Kościół i Prawo 4 (2015): 141-168.

Sobczyk, Paweł. „Konstytucyjna zasada równouprawnienia Kościołów i innych związków wyznaniowych". W: Problemy państwa i prawa, red. Feliks Prusak, 21-35. Warszawa: Oficyna Wydawnicza WSM SIG, 2004.

Sobczyk, Paweł. „Konstytucyjne «prawo osób do korzystania z pomocy religijnej tam, gdzie się znajdują»". W: Wolność sumienia i religii osób pozbawionych wolności. Aspekty prawne i praktyczne, red. Jerzy Nikołajew, Konrad Walczuk, 82-96. Warszawa: Wydawnictwo Unitas, 2016.

Stanisz, Piotr. „Naczelne zasady instytucjonalnych relacji państwo - kościół”. W: Artur Mezglewski, Henryk Misztal, Piotr Stanisz, Prawo wyznaniowe. Warszawa: Wydawnictwo C.H. Beck, 2011.

Winczorek, Piotr. Komentarz do Konstytucji Rzeczypospolitej Polskiej z dnia 2 kwietnia 1997 roku. Warszawa: Wydawnictwo „Liber”, 2008.

Winiarczyk-Kossakowska, Małgorzata. Ustawy III Rzeczypospolitej o stosunku Państwa do kościołów chrześcijańskich. Warszawa: Dom Wydawniczy „Elipsa”, 2004. 
Wiśniewski, Piotr. „Osoba pozbawiona wolności - na podstawie wyroku lub postanowienia sądu - jako podmiot konstytucyjnej gwarancji wolności sumienia i religii. Aspekt teoretyczny. Zagadnienia wybrane". W: Wolność sumienia i religii osób pozbawionych wolności. Aspekty prawne i praktycz$n e$, red. Jerzy Nikołajew, Konrad Walczuk, 97-111. Warszawa: Wydawnictwo Unitas, 2016.

\author{
FUNCTIONING OF PRISON PRIESTHOOD \\ AS AN EXPRESSION OF EQUALITY OF CHURCHES \\ AND RELIGION ASSOCIATIONS IN POLAND
}

\title{
Summary
}

In this text, the way of realization of the equality principle of churches and religious associations towards the state is introduced. The principle is one of the most essential in the system of the contemporary Polish religious law in relation to the functioning of the priesthoods in the national penitentiaries.

Ttumaczenie wtasne autora

Key words: churches, religious associations, principle of equality, the prison system, freedom of conscience and religion

Słowa kluczowe: kościoły, związki wyznaniowe, zasada równouprawnienia, system penitencjarny, wolność sumienia i wyznania 